This is a so-called personal version (author's manuscript as accepted for publishing after the review process but prior to final layout and copyediting) of the article:

Hellgren, B., Löwstedt, J., Puttonen, L., Tienari, J., Vaara, E. and Werr, A. How issues become constructed in the media: 'Winners' and 'Losers' in the AstraSeneca merger. British Journal of Management, 2002, 13(2), 123-140.

Researchers are kindly asked to use the official publication in references.

\title{
How Issues Become (Re)constructed in the Media: Discursive Practices in the AstraZeneca Merger
}

\author{
B. Hellgren,
}

Linköping University

\section{J. Löwstedt}

Stockholm School of Economics

\section{Puttonen}

Helsinki School of Economics

\section{J. Tienari}

Lappeenranta University of Technology,

Department of Business Administration, Box 20, 53851 Lappeenranta, Finland janne.tienari@lut.fi

\section{E. Vaara}

Svenska handelshögskolan,Helsingfors

\section{A. Werr}

Stockholm School of Economics 


\begin{abstract}
In this article, we put forward a novel way of exploring difference and contradiction in merging organizations. We examine how the media (re)constructs meanings in a major crossborder merger. Based on an analysis of press coverage, we attempt to specify and illustrate how particular issues are (re)constructed in media texts through interpretations of 'winning' and 'losing'. We also show how specific discourses are drawn on in this (re)construction. In the merger studied, discourse based on economic and financial rationale dominated the media coverage. Discourse promoting nationalistic sentiments, however, provided an alternative discursive frame to the dominant rationalistic discourse. We argue that the two basic discourses are enacted in three analytically distinct discursive practices in the media: factualizing, rationalizing and emotionalizing. We suggest that the ability of different actors such as top managers to make use of different discursive strategies and resources in promoting their 'versions of reality' in the media (or public discussion) is a crucial avenue for research in this area.
\end{abstract}

\title{
Introduction
}

Media texts are arguably an important site for the constitution and reconstitution of organizational change, of which mergers and acquisitions are particularly dramatic examples (cf. Vaara and Tienari, 2002). Although the decision to merge is carried out by the owners and top executives of companies, merging is performed in a wider social and societal context (Hellgren and Löwstedt, 2001) where multiple interpretations or 'realities' are possible. In this context, the media can be seen as both a sense-maker and a sense-giver (cf. Gioia and Chittipeddi 1991; Weick, 1995). The media is a sense-maker in that it takes part in developing a meaningful framework for understanding complex phenomena such as mergers. The media is a sense-giver in that it also attempts to influence sense-making and meaning construction among its audiences toward specific definitions of 'reality'. In this article, we explore how the media socially (re)constructs meanings in a cross-border merger.

Earlier literature on mergers and acquisitions suggests that identification of 'winners' and 'losers', and making sense of a winner-loser setting, is an essential part of post-merger organizing (Vaara, 2000). In this identification and sense-making, specific themes - or issues - tend to come to the fore. Division of ownership, choice of top executives, location of headquarters, allocation of resources and distribution of staff reductions are examples thereof. 
Apart from their material significance, such choices carry symbolic meaning (Meyer, 2001; Olie, 1994) as 'cultural' representations.The contention is that 'cultural' identification, contradiction and difference plays a crucial role in intra- and inter-organizational sensemaking in the context of mergers and acquisitions (Gertsen, Söderberg and Torp, 1998; Nahavandi and Malekzadeh, 1988).

The ways in which issues become constructed and reconstructed in media texts, however, seems to be an under-researched area in management studies and organization theory. This is despite the fact that the increasing influence of mass media in assigning or fixing particular meanings to 'reality' in contemporary societies has been subject to critical scrutiny by, for example, linguists (Chomsky, 1999; Fairclough, 1995) and sociologists (Bourdieu, 1998a, 1998b). It is evident that the conventions and practices of the media carry wider significance. The media promote particular versions of 'reality' and marginalize and exclude others. The discursive narrowing down of social and organizational life in neoliberal terms is a point at hand, as social relations are restructured and rescaled in accord with the demands of an unstrained global capitalism (Bourdieu, 1998a, 1998b; Fairclough, 2000). We attempt to make explicit some of the practices of the media: how texts are constructed in the merger context. This entails both a wider scanning of media material and detailed analysis of individual texts.

In this article, we put forward a novel framework for exploring merging. We make an attempt to demonstrate how specific issues become constructed and reconstructed in media texts on a cross-border merger through interpretations of 'winning' and 'losing'. Furthermore, we elaborate on the types of practices through which specific discourses are enacted in this identification. We focus on the recent merger between the pharmaceutical companies Astra (Sweden) and Zeneca (United Kingdom). We examine how selected printed media in the two countries have covered the merger. In so doing, we draw from both content analysis of textual material and critical discourse analysis (cf. Fairclough, 1997).

In the following, we first briefly summarize different strands of recent literature on mergers and acquisitions. We go on to outline a framework for analysing media texts in the crossborder merger context. We then reflect briefly on our method and data, and present our analysis of the merger between Astra and Zeneca. Finally, we offer conclusions and directions for future research. 


\section{Mergers and acquisitions in a nutshell}

Management and organization research on mergers and acquisitions reflects a range of different traditions. One can, for example, distinguish between strategic, human resource management, cultural and alternative perspectives in this growing literature. Since the 1960s, mergers and acquisitions have been studied from a strategic perspective, with close links to economics and later finance literature. Studies from this perspective have typically concentrated on the decisionmaking processes and the performance effects of mergers and acquisitions (cf. Kitching, 1967; Haspeslagh and Jemison, 1991; Pablo, 1994). These studies have typically been based on attempts to understand management as a rational, unified agent solving organizational problems.

Studies adopting a human resource management perspective have provided a contrast to the more strategically oriented analyses. These studies have often sympathized with employee concerns in the emergent, merger-related change processes, and closely examined employee reactions leading to compliance or resistance to change (e.g. Cartwright and Cooper, 1990; Napier, 1989; Schweiger, Ivancevich and Power, 1987). Closely linked to these studies, with the rise of a more general interest in the study of 'culture' since the early 1980s, researchers started to explore mergers and acquisitions from a cultural perspective (Buono, Bowditch and Lewis, 1985; Nahavandi and Malekzadeh, 1988). Accordingly, a growing stream of studies has emerged with a focus on cultural differences and contradictions at organizational (or corporate) and national levels (e.g. Calori, Lubatkin and Very, 1994; Gertsen, Söderberg and Torp, 1998; Lubatkin et al., 1998; Olie, 1994). Studies with a cultural perspective have mainly concentrated on culture clashes occurring in different types of acculturation, or cultural integration, process (e.g. Krug and Hegarty, 1997) and, again, on their effects on corporate performance (e.g. Chatterjee et al., 1992; Datta, 1991; Morosini, Shane and Singh, 1998). Larsson and Lubatkin (2001) have examined a sample of case studies to analyze crossnational culture clashes, and conclude that 'social controls' by the acquiring firm are likely to contribute to the desired acculturation. In general, the need for appropriate action seems to be the message in much of the HRM and cultural literature on mergers and acquisitions.

In parallel to the dominant perspectives, a number of alternative frameworks have recently been introduced to the literature on mergers and acquisitions. These include cognitive simplification (Duhaime and Schwenk, 1985), rationalities (Ericson, 1991), organizational justice (Meyer, 2001; Very, Lubatkin and Calori, 1998), ambiguity (Risberg, 1999) and 
organizational politics (Vaara, forthcoming). However, it seems that relatively few studies have been interested in the wider societal consequences of mergers and acquisitions or adopted an inherently critical perspective. The few studies that have paved the way in this direction include Davis and Stout (1992) and Thornton (1995), which consider mergers and acquisitions as examples of social movements and fashions, Lubatkin and Lane (1996), which points to the crucial role of consultants and investment bankers in these processes, and Tienari (2000), which illustrates how mergers can be conceptualized as social domains producing and reproducing gender segregation.

Studies that seriously consider the discursive elements in mergers and acquisitions are apparently still rare. Important exceptions are studies by Hirsch (1986), which examines the metaphors and vocabularies of hostile takeovers, and by Schneider and Dunbar (1992), which provides a psychoanalytic reading of hostile takeover events. Vaara and Tienari (2002) studied media texts on several mergers and acquisitions. They analysed how texts work within sociocultural practice (cf. Fairclough, 1997), and pointed to specific types of discourse through which the changes involved in mergers and acquisitions were justified, legitimized and naturalized in the media.

\section{Mergers and media: how issues become (re)constructed}

While most organization scholars have used the concept of issue to refer to intraorganizational sense-making processes (see e.g. Dutton and Dukerich, 1991; Weick, 1995), we suggest that it is also fruitful to conceptualize publicly debated questions as issues. This approach helps us to understand how in specific cases that receive significant public attention, the organizational sense-making processes are not constrained by (imaginary) organizational boundaries. The media, for example, take part in giving sense to these discussions (cf. Gioia and Chittipeddi, 1991). It has also been suggested that topics or issues debated in a merging organization may to some extent be determined by the public discussions (cf. Frommer, 2001). An approach taking into consideration the role and influence of the media enables us to see how specific issues become constructed and reconstructed as significant for certain actors, and to comprehend how and why issues often become politicized. Furthermore, it enables us to consider the discursive strategies of different actors in promoting or questioning (organizational) change - such as the merger - in relation to specific issues (cf. Hardy, Palmer and Phillips, 2000). 


\section{Multiple voices}

It should be noted that a large part of the most intense public discussions on mergers and acquisitions takes place during a relatively short period after their announcement. This means that there is still little 'knowledge' of their longer-term consequences and that the discussions are therefore likely to be characterized by uncertainty. Mergers and acquisitions are driven by multiple motives (Haspeslagh and Jemison, 1991; Trautwein, 1990). A speculative element is also ever present when issues are discussed in public. The potential for multiple and contradictory interpretations, and asymmetries between these interpretations, brings in the question of power; discourse events are marked by unequal capacities to control how texts are produced, distributed and consumed (cf. Fairclough, 1997). The media is by no means a neutral sense-maker and sense-giver in providing frames of reference for their audiences.

Relatedly, different actors' discursive strategies become realized in media texts in different ways. This can be approached by the idea of voices. In media texts, specific actors do not necessarily speak in a single voice. Rather, voices tend to be tied to specific subject positions and identities made available by discourses (Fournier, 1998; Vaara and Tienari, 2002). The important thing for the researcher, then, is to locate discourses in media texts, and make explicit and account for which voices become dominant, which are marginalized and which are absent in these discourses - and, at best, attempt to account for why this is so.

Top managers with the 'legitimate formal power' to orchestrate the change processes following mergers and acquisitions may be of particular interest here. Their talk and actions are often the primary focus of media attention. At the same time, managers are gatekeepers for much of the information circulated and discussed. This creates a peculiar power position for the managers vis-à-vis other actors. It is also clear that the managers in charge - as a collective and as individuals - have vested interests in the public discussion. It is important to gain acceptance and legitimization for the initial merger or acquisition decision as well as the subsequent initiatives for organizational change (Vaara and Tienari, 2002).

Initiatives for organizational change in merging often involve decisions on allocation (Meyer, 2001) and controversial measures such as reductions in personnel (Tienari, 2000). Controversiality results in the decision-makers' need to justify the actions taken. This is reflected, for example, in the vast body of literature concentrating on organizational 
communication in mergers and acquisitions (e.g. Napier, Simmons and Stratton, 1989; Risberg, 1999; Schweiger and DeNisi, 1991).

Furthermore, from a managerial point of view, it is thus no trivial matter how the merger or acquisition is being portrayed in the media. If the media reports and reproduces the managers' thoughts concerning a need for industrial restructuring and a demand for creation of competitive strength, this easily convinces the reader of the necessity of the merger (Vaara and Tienari, 2002). In turn, if the media focus on the employment concerns and emphasize the loss of jobs, the image may become negative and the merger is not immediately accepted in public (ibid.). Furthermore, managers also seek positive public recognition as individuals. On the one hand, this creates a need for managers to emphasize the successful features of the business arrangements at hand and a need for attribution of credit. On the other hand, in situations of negative assessment there is a need to play down responsibility. This has been demonstrated in studies of managers' narratives of cross-border acquisitions (Vaara, forthcoming).

Vaara and Tienari (2002) identified rationalistic discourse as the core in the ways in which 'changes' involved in mergers and acquisitions are justified, legitimized and naturalized in the media. Rationalistic discourse works through specific themes and voices to convince the reader of the legitimacy of economic and financial rationale in merging or acquiring. Managers, for example, tend to justify mergers and acquisitions in public discussion in terms of economic and financial rationale; their voices make use of the rationalistic discourse through specific themes such as rationalization (staff dismissals) and competitiveness (ibid.). The study by Hellgren, Löwstedt and Werr (2000) on the concept of efficiency in media texts on a cross-border merger also points to the direction of the dominance of the rationalistic discourse.

\section{'Winners', 'losers' and nationalistic discourse}

The question of picking out 'winners' and 'losers' in business events such as mergers may be considered an example of how specific actors become voiced and contrasted. This is based on the journalists' need to create good stories. Conceptions of winning and losing may simply take the form of personification or organizational (or 'cultural') identification in media texts. However, national identification may also become the platform of the 'winner' and 'loser' setting, especially in a cross-border merger or acquisition. Identifying merging companies, 
and key individuals therein, as representatives of specific nations broadens questions of winning and losing into a framework of nationalistic discourse (Risberg, Tienari and Vaara, 2000; Vaara and Tienari, 2002). This discourse articulates specific collective, national identities. The nationalistic counterbalance to the typically dominant rationalistic discourse may then provide ways in which the merger idea can be critically scrutinized in media texts.

We build our analysis on the idea that the meaning of nation is socially constructed and reconstructed in discourse (De Cillia, Reisigl and Wodak, 1999), as is economic or financial rationalism. In general, nationalism may be conceptualized as 'an ideology which legitimates the existence and activities of territorial states on the basis of characteristics ("ethnic", cultural, linguistic, historical, etc.) supposedly shared by, and specific to, their inhabitants' (Low, 2000, p. 356). Billig's (1995) concept of banal nationalism is particularly useful in the study of media texts as it refers to how the construct of nation is often reproduced and accepted mindlessly and uncritically, rendered possible by mundane habits of language, thought and symbolism. For example, when a journalist uses the term 'we' in a text to refer to a specific national collective, s/he is involved in the myriad of processes (re)constructing the 'nation' (ibid.).

Nationalism itself depends, however, on a set of deeply-held images of historical time and community. Narratives of origin and destiny are central to its (re)construction. Anderson (1983) talks about imagined, invented histories of nationalism. De Cillia et al. (1999) have examined topics, discursive strategies and linguistic devices which are employed to construct, on the one hand, national sameness and uniqueness, and, on the other hand, distinctions and differences from other national collectives. They build on Anderson's (1983) seminal work, and argue that national identities are 'discursively, by means of language and other semiotic systems, produced, reproduced, transformed and destructed' (De Cillia et al., 1999, p. 153). The media are likely to play a crucial role in (re)constructing national identities.

\section{Argumentation and discursive practices}

Specific issues, and the related 'winner' - 'loser' settings, become constructed and reconstructed in the media in different ways as specific discourses are drawn on. Rationalistic and nationalistic discourses were discussed above. Finally, in accounting for how and why journalists operate on discourses, we introduce the concept of argumentation to the research framework. Journalists construct and reconstruct legitimacy to, and naturalize, phenomena 
through means of argumentation and rhetoric (Kuronen, Tienari and Vaara, 2001; cf. Mazza and Alvarez, 2000). To give sense, then, is about attempts to influence the sense-making of others, as has been argued in the organizational context (cf. Gioia and Chittipeddi, 1991).

A key notion in the study of argumentation and rhetoric is that argumentation is needed when there is doubt that the claim(s) and fact(s) presented by the speaker may be questioned by the audience. The audience's acceptance of, or support for, the claim or claims presented is being earned or affirmed through argumentative means (Perelman and Olbrechts-Tyteca, 1971; Perelman, 1977). The discussion on multiple issues and voices above suggests that the merger is a fruitful context for multiple claims and rhetorical means. In other words, the speaker (here, the journalist) seeks to influence the conation of the audience (here, the readers) in order to gain acceptance for a specific claim or claims. The speaker does so by convincing and persuading the target audience. The three classic elements of rhetoric are ethos (a claim to credibility based on the authority of the speaker), pathos (appealing to the audience's emotions) and logos (the logical or cogent argument).

The conventions and practices of the media are informed by time pressures and the restricted amount of space available for individual texts. Thereby, the media arguably objectifies complex and ambiguous phenomena such as 'necessary changes' in a merging organization. In constructing their texts, journalists choose particular issues and (actors') voices over others. In being forced to make choices, they may also concentrate on saying what they think their target audience wants to hear (Bourdieu, 1998a).

In the present study, we are interested in specific discursive practices; general, recurring ways through which speakers, i.e. journalists, attempt to convince their audience, i.e. readers, of specific claims in their texts. Here, we refer particularly to issues and the related 'winner' 'loser' settings in the merger context. The study of discursive practices helps to uncover the ways in which discourses such as the rationalistic and nationalistic are enacted in individual media texts. Fairclough (1997) works on the concept of discourse practice in studying processes of text production, distribution and consumption. This concept 'ensures attention to the historicity of discursive events by showing both their continuity with the past (their dependence upon given orders of discourse) and their involvement in making history (their remaking of orders of discourse)' (ibid., p. 11). According to Fairclough (1997), for any discursive event, producers and interpreters of texts draw upon socially available resources that constitute the order of discourse, that is, a historically particular structuring of text- 
producing practices. To simplify somewhat, we consider discursive practices as means through which discourses become enacted in a specific sociohistorical setting.

Finally, two clarifications must be made. First, we think it relevant to conceptually distinguish between discourses as language systems promoting specific meanings and discursive practices as ways of enacting discourses. Empirically the two are likely to appear closely knit. Second, our distinction between different discursive practices, too, is an analytical and interpretative effort. It is thus open to critical scrutiny. Disentangling various discourses and discursive practices, however, helps to address the specific meanings fixed to complex phenomena. The merger context remains marked by ambiguity and uncertainty.

\section{Method and data}

In the present study, we examine how meaning is socially (re)constructed in the merger between the pharmaceutical company Astra (Sweden) and the pharmaceuticals and chemicals group Zeneca (United Kingdom), in printed media in the two countries. Our analysis has proceeded in two steps.

First, we scanned the content in the media coverage of the AstraZeneca merger in selected Swedish and UK newspapers and business outlets. For our Swedish material, we searched the Affärsdata database on the Internet for texts with 'Astra' and 'Merger' in the title. This database includes the major Swedish business outlets Dagens Industri (available since 1981), Finanstidningen (1992), Affärsvärlden (1993) and Veckans Affärer (1982), as well as the business sections of the major daily newspapers Svenska Dagbladet (1992) and Dagens Nyheter (1992). For our UK material, we searched the databases of selected journals on the internet for texts with 'Astra', 'Zeneca' and 'Merger' in the title. We selected the Financial Times and The Economist (major business outlets) as well as The Guardian, Daily Telegraph and Sunday Telegraph (major newspapers with different political profiles) to match our Swedish In the content analysis of the media material, we focused on identifying recurring issues, i.e. issues which could thus be interpreted as significant. We also considered how Astra (or 'Swedish') and Zeneca (or 'British') viewpoints and interests, and the juxtaposition between them, are manifest vis-à-vis the issues identified. Table 1 summarizes the textual material in our study (it should be noted that a large part of the texts in Financial Times are short news reports). 
Second, after identifying issues and mapping out the juxtaposition of different viewpoints and interests, we carried out a more in-depth discourse analysis on selected - in our view both typical and revealing - individual texts from the material (cf. Fairclough, 1997). We employed a version of an 'interdisciplinary approach that combines historical, socio-political and linguistic perspectives’ (De Cillia et al., 1999, p. 157) in locating and situating texts and discourses in their context. We made an attempt to identify discourses and discursive practices in the texts. We viewed individual texts as incomplete in the sense that they are filled with meaning only when the reader connects them to other texts. Intertextuality is thus a crucial element in our work; one basis for our 'readings' (cf. Fairclough, 1997).

In the following, the empirical part of this article consists of two main sections. In the first section, we present an overview of the main issues in the media coverage in the merger between Astra and Zeneca, and discuss the relation of these issues to the (re)construction of 'winner' - 'loser' settings, and the discourses involved. In the second section, we proceed to specify discursive practices in the media coverage.

Table 1. Media Material

\begin{tabular}{|l|l|l|l|}
\hline $\begin{array}{l}\text { Information } \\
\text { sources }\end{array}$ & Number of texts & $\begin{array}{l}\text { Number } \\
\text { of texts }\end{array}$ & Time range \\
\hline UK & Financial Times & 159 & $\begin{array}{l}25.03 .1996-23.10 .1999 \\
07.01 .1999-11.10 .2000 \\
23.01 .1998-23.12 .2000 \\
10.12 .1998-23.11 .2000\end{array}$ \\
& $\begin{array}{l}\text { The Guardian, The Guardian Unlimited } \\
\text { and The Observer }\end{array}$ & 41 & \\
& Daily Telegraph and Sunday Telegraph & 50 & \\
& The Economist & 5 & $10.06 .1998-01.03 .2000$ \\
& Total & 255 & $23.12 .1995-10.11 .1999$ \\
\hline Sweden & Affärsvärlden & 9 & $08.03 .1996-16.06 .1999$ \\
& Dagens Industri & 34 & $29.11 .1996-12.12 .1999$ \\
& Dagens Nyheter & 12 & $14.12 .1998-13.09 .1999$ \\
& Finanstidningen & 39 & \\
\hline $\begin{array}{l}\text { Total number } \\
\text { of articles }\end{array}$ & Svenska Dagbladet & 28 & \\
\hline
\end{tabular}




\section{Re)constructing issues: 'winners' and 'losers'}

Consolidation, or concentration, through mergers and acquisitions is clearly evident in the contemporary global pharmaceutical industry. Llewellyn (2000) identifies three main reasons behind this trend: cutting costs through eliminating overlapping operations, extending the scope of the companies' sales forces and increasing the opportunities and funding for research and development.

The pharmaceutical company Astra (Sweden) and the pharmaceuticals and chemicals group Zeneca (UK) agreed upon what was termed a merger of equals on 9 December 1998. Before the official announcement of the merger plan, both companies were surrounded by many acquisition or merger rumours; with each other or with other pharmaceuticals of similar size and suitable business area.

Mr Håkan Mogren, CEO of Astra, and Sir David Barnes, CEO of Zeneca, were old acquaintances. Rumours of a merger between the two companies became stronger when Astra and Merck (a US pharmaceutical company) agreed to terminate their cooperative contract. Astra bought Merck out of the joint venture Astra Merck Inc (cf. Llewellyn, 2000). After having agreed upon the merger, the decision-makers in Astra and Zeneca still needed approval from their shareholders, the competition officials of the commission of the European Union, and the US Federal Trade Commission. During this period, rumours of a hostile bid for Zeneca were several. Finally, the proposed merger received approval from shareholders of both Astra and Zeneca. The agreement became effective on 6 April 1999.

'AstraZeneca, which will have its headquarters in London, will be the fifth largest company in the UK, with a market capitalization of about £53bn, and will make up 4.3 per cent of the FTSE 100 index by value.' (Financial Times, 7 April 1999)

The merger between Astra and Zeneca raised a great amount of public discussion in Sweden and in the UK. Based on the content analysis of the present press material it is apparent that the construction of a 'winner' - 'loser' setting centred around four main issues in the texts: (1) division of ownership, (2) distribution of top management positions, (3) locations; company headquarters as well as main R\&D operations, and (4) staff reductions. We use the present tense in the following in specifying and illustrating these issues in context. A summary on the 
(re)construction of issues through interpretations of 'winning' and 'losing' is presented at the end of the section.

\section{Division of ownership}

The merger of Astra and Zeneca is launched as a 'merger of equals'. The ownership of the new company AstraZeneca is divided on the basis of the stock value of the merging companies on the day of the merger agreement. It seems that the British press treats the ownership question relatively neutrally. An extract from the Financial Times exemplifies this:

'Zeneca's shareholders will have 53.5 per cent of the merged company and those of Astra will have 46.5 per cent.' (Financial Times, 12 December 1998)

The Financial Times (FT) informs its readers about what has been agreed on. The neutral tone in the reporting can derive from the fact that being neutral is the style of the FT, and/or that the terms of the deal are taken to satisfy the British stakeholders, i.e. the newspaper's primary readers. Considering the media coverage of the Astra- Zeneca merger in general, it seems that the merger is widely accepted in the UK from the beginning (this is also evident in Llewellyn, 2000).

In contrast, the Swedish press treats the ownership issue in AstraZeneca as more ambiguous and subject to contesting viewpoints. The Swedish Small Shareholders Association, for example, is often voiced in such texts. In a number of articles the issue is argued as if Astra's shareholders had lost out in the merger. In general, there are two lines of reasoning behind this in the texts. First, Astra is a better performing company than Zeneca. Second, Astra's share price was at a low point at the time of the merger decision. The text below, published in a major Swedish daily newspaper, discusses the relative difference between the ownership percentages:

'The two companies’ advisors, Morgan Stanley for Astra and Goldman Sachs for Zeneca, arrive at this [division of ownership] in their assessments. But on a deeper level, the problem is more complex ... . One way of comparing Astra and Zeneca is to look at how efficiently they use their personnel and capital resources to create value added. This analysis shows . . . that Astra is much more effective than Zeneca, if Astra's large and low-return cash assets are taken out of the calculations.' (Svenska Dagbladet ekonomi, 24 January 1999) 
The terms of the merger are thus criticized on the basis of the method used to assess the companies. A more rigorous (and more 'fair') analysis would have worked in favour of the Swedish Astra, which now remains the 'loser' vis-à-vis the terms of the merger.

\section{Distribution of top management positions}

The top management positions in the new company AstraZeneca are distributed 'equally' between the two companies. On a general level, both the British and the Swedish press seem to share the view on the importance of a clear top management structure settled already in the merger negotiation phase. The Financial Times describes the composition of the top management as follows:

'Tom McKillop, head of pharmaceuticals at Zeneca, was named as chief executive, with Percy Barnevik, the Swedish industrialist, as chairman, and Sir David Barnes from Zeneca and Hakan Mogren from Astra as deputy chairmen.' (Financial Times, 10 December 1998)

Such 'equality' can also be portrayed as a necessary compromise, bearing in mind earlier failed merger attempts in the pharmaceutical industry. Such failures are interpreted to have resulted from disputes between top executives over the 'Number One' position in the new company:

'The 14-man board has been carved out equally between both companies, which smacks of classic compromise but is probably a reaction to the failure of Glaxo Wellcome and SmithKline Beecham earlier this year to complete their deal.' (Daily Telegraph, 10 December 1998)

Clarity then becomes the key word parallel to 'equality' in the top management issue. The whims of the market are satisfied with a firm hand:

“"It was absolutely vital to have a clear command structure,” said Sir David Barnes, Zeneca's chief executive, yesterday. "There is a clear-cut, black-and-white authority for the chief executive officer, Tom McKillop.” . . . “A key strength of the deal is that they have sat down, thought the management structure through and laid it out in a lot of detail,” said Mike Standing, head of life sciences at Cap Gemini, a consulting and IT firm. They had learnt the lessons of the failed Glaxo Wellcome/ SmithKline 
Beecham merger, he said, which collapsed earlier this year amid managerial conflicts.' (Financial Times, 10 December 1998)

The top management issue seems settled in AstraZeneca. 'They had learnt the lessons' of earlier merger attempts in the industry. The voice of the 'expert' (consultant) confirms this for the readers of the Financial Times, and thereby assists in legitimizing the viability and sensibility of the deal.

Beneath the overall picture of uniformity between the British and Swedish texts, however, a difference becomes apparent. On the one hand, the Daily Telegraph points out the confusing factor in the top management structure. Tom McKillop’s former boss, Sir David Barnes, is the deputy chairman in the new organization. This structure ranks the deputy chairman above the CEO, but at the same time states that the role leads to 'undertaking executive activities' at the request of the CEO (Daily Telegraph, 10 December 1998). In all, it seems that a traditional hierarchical command structure is reproduced in British media texts as both natural and good, and that AstraZeneca's structure is a confusing deviation from this.

On the other hand, the Swedish press is concerned about how Håkan Mogren, the former CEO of Astra, can cope with his role as a deputy chairman, which includes taking orders from the new CEO:

'For more than 20 years he [Håkan Mogren] has been a CEO of Swedish companies, first of Marabou, and then for about 10 years of the ever brighter crown jewel Astra. It is no surprise that many people ask how Håkan Mogren will handle the inferior role as deputy chairman of the board of Astra Zeneca . . . Håkan Mogren says that he wanted this specific position. He says that he sees it as a promotion, not a demotion.' (Svenska Dagbladet ekonomi, 12 December 1998)

Håkan Mogren’s claims of being satisfied with his new position do not, however, seem to be accepted in the Swedish press. Rather, power games are assumed, indicating that Mogren lost the position he had aspired for: 'One can only speculate about which forces have been active backstage’ (Affärsvärlden, 13 January 1999). The Swedish press also point out a concern about the future management of AstraZeneca:

'The executive power, however, is already in British hands. Even if Swedish representation among the top executives is strong today, it is striking that the 
Swedish members as a group are much closer to retirement than their British colleagues.' (Svenska Dagbladet ekonomi, 18 April 1999)

The balance of power, and the 'winner'-'loser' setting, is in this way not only portrayed explicitly as a setting between 'Brits' and 'Swedes'. It is also projected to the future.

\section{Locations}

The headquarters of the new company, Astra- Zeneca, will be located in London. This issue is treated notably differently by the UK and Swedish press. Again, the Financial Times offers an example of a matter-of-fact way of reporting an issue (similar statements can be found in texts in the other British media studied):

'While it was seen as a merger of equals, its corporate headquarters are to be in London.' (Financial Times, 12 December 1998)

It may be self-evident for British journalists that when a UK company merges with a company from a smaller country the headquarters will be located in London, one of the major centres of business in Europe. In Swedish press, however, the decision to locate the headquarters in London is conceived of as a visible sign of 'losing' in the merger. The relative importance of Astra in Sweden has been greater than that of Zeneca in the UK. Affärsvärlden, for example, comments on the ongoing public debate in Sweden about the location of company headquarters:

'That headquarters will be located in London and AstraZeneca will be seen as a British company has evoked strong emotions. Many perceive it as a national disaster for Sweden and wonder why politicians don’t seem to care.' (Affärsvärlden, 13 January 1999)

This quote reflects the Swedish concern for 'losing' as a nation. It reflects a vivid, wider debate in Sweden at the time of the AstraZeneca merger, a debate triggered by the relocation of a number of large Swedish firms' headquarters. Swedish-led multinational companies have for a long time been the driving force of the country's economy (Blomström, 1990). Yet, influential Swedish companies have in their recent cross-border mergers agreed to locate the headquarters of the new company outside Sweden. In addition to 'Sweden', the issue of the location of headquarters is also related to concerns about the decreasing importance of the Stockholm Stock Exchange, constructed as a 'losing' actor (one among several) in the merger. 
While the company headquarters will be located in London, the headquarters of the main research and development operations of Astra- Zeneca will be located in Södertälje, Sweden. Södertälje is a relatively small industrial town south of Stockholm.

The R\&D location issue is treated differently in the UK and Swedish press. Journalists in the UK are now concerned with the decision, and construct the British Zeneca as the 'loser':

'For instance, the research headquarters of Astra Zeneca will be in Sweden while large parts of the UK's competence in industrial chemistry has been parceled out to foreign owners. Is British science being hollowed out? Meanwhile, Zeneca’s merger with a Swedish company of around its own size means that no part of the old ICI remains separately identifiable.’ (Financial Times, 10 December 1998)

This text illustrates that the Financial Times, which we depicted above in terms of its matteroffact reporting, is also capable of more nationalistic discourse (note e.g. 'British science'). For the Guardian, locating main research and development operations in Sweden is an issue of concern from the point of view of control:

'And the merger of Zeneca with Astra of Sweden, will see the UK pharmaceutical group's research and development headquarters switched to Stockholm - where London’s control will be diminished.' (Guardian, 6 February 1999)

It is clear that 'London's control' is (re)constructed as something desirable. The possible diminution of this control is of national importance. Nationalistic discourse, and the question of 'loss' within its parameters, is even more clearly demonstrated in another text from the Guardian (note also the reference to Stockholm instead of Södertälje):

'But Zeneca has moved its R\&D headquarters to Stockholm, which may weaken the $R \& D$ base in pharmaceuticals - one of the few areas where Britain possesses a genuinely world-class industry.' (Guardian, 20 July 1999)

In turn, the Swedish press now reports it as a rational choice to locate research and development headquarters in Södertälje. It is a question of 'equality' since the company headquarters are located in London. It is also logical since Astra has invested considerably in research and development in the past: 
'The solution to manage research and development from Södertälje can also contribute to a smoother implementation of the merger. However, some fear that this solution is only temporary in order not to unnecessarily upset the researchers.' (Veckans Affärer, 1 February 1999)

While Swedish journalists welcome Södertälje as the headquarters for research and development operations, they also project the decision into the future. In so doing, they raise concerns about possible upcoming developments in the Swedish- British company. A 'win' for Sweden may be only temporary, contrary to the views expressed by Swedish managers in AstraZeneca.

\section{Staff reductions}

Reaping synergy benefits by cutting overlapping operations is a typical objective in a 'merger of equals'. There is initial speculation about reductions of a total of 6000 jobs in the merger between Astra and Zeneca. The top managers of both companies emphasize in public that the reductions - mainly concerning administration, sales and manufacturing - are to be handled to a large extent through retirement schemes and voluntary redundancies. The British press seems to report the issue of staff reductions in a relatively 'neutral' manner:

'Drugs giant Zeneca yesterday unveiled the terms of its $£ 46$ billion merger with Swedish rival Astra and revealed that the deal will involve 6,000 job losses worldwide.' (Daily Telegraph, 10 December 1998)

It is interesting to note that when the Financial Times speculated on a merger between Zeneca and Astra in early Autumn 1998, i.e. prior to the actual announcement of the merger, the issue of staff reductions related to research and development operations (e.g. 17 August 1998). Now it is the jobs in administration that 'are to go' (12 December 1998).

Furthermore, it is evident in the British media texts that of the 6000 job losses estimated at the outset of the merger, up to 1000 will be lost in the UK:

'Zeneca chief executive Sir David Barnes said up to 1,000 British jobs could go over the next three years. He said: "I believe the job reductions can be handled sensibly, humanely and responsibly.” Administration, sales and manufacturing operations are likely to bear the brunt of the cuts, with research and development relatively untouched.' (Daily Telegraph, 10 December 1998) 
The matter-of-fact tone in the British texts may be due to two reasons. In the UK, an announced loss of 1000 jobs is not necessarily media headline material. Also, as the headquarters of Astra- Zeneca will be located in London, the pressure to reduce staff in 'administration' first and foremost affects operations in Sweden.

The issue of staff reductions is discussed with more nuance in the Swedish press. Uncertainty surfaces in the texts (e.g. Dagens Nyheter ekonomi, 18 December 1998). This may be because the majority of the reductions are to take place in Sweden (the number of reductions planned within AstraZeneca's operations in the USA is not evident in any of the texts included in our study). Management is yet constructed as a responsible actor in carrying out the staff dismissals:

'Respect for the employees is a keyword for Claes Wilhelmsson who will be responsible for research and development in AstraZeneca.' (Svenska Dagbladet ekonomi, 14 January 1999)

In both UK and Swedish media texts, the issue of staff reductions is constructed through a setting where the identification of 'winners' and 'losers' is not as explicit as in relation to the other issues identified. It seems obvious for journalists that both sides are to 'lose' to some extent, due to the nature of the issue of staff reductions in mergers in general. The issue itself does not seem to become challenged.

\section{Summary: the (re)construction of issues}

In sum, it is evident that in the cross-border merger context, issues are (re)constructed through interpretations of 'winning' and 'losing'. Interestingly, media texts on the 'winning' side tend to construct each issue in question in an apparently rational, neutral and matter-of-fact way, while the 'losing' side also tend to revert to nationalistic considerations.

For example, both key questions of geographical location are constructed as 'winner'-'loser' settings. In discussing the location of the headquarters of AstraZeneca in London, British media texts tend to establish the headquarter location as a relatively straight-forward 'fact'. Swedish media texts provide a contrast to this reporting as claims about Swedish society losing out on this issue are reproduced. 'Sweden' is explicitly (re)constructed as a nation (cf. Billig, 1995), and the AstraZeneca merger is placed in a wider context of national 'loss'. In discussing the issue of locating the main research and development operations of Astra- 
Zeneca in Sweden, however, the British press markedly draw from nationalistic discourse. Swedish press, in turn, adhere to a form of rationalism in justifying the choice as both fair and logical.

\section{Discursive practices in (re)constructing issues}

In the above section, we identified four issues in Swedish and UK media texts on the AstraZeneca merger. These issues represent controversies interpreted and mapped out in the media in the form of 'winner'-'loser' settings. In the following, we will look more deeply into the constitution of these controversies through individual examples of texts.

We identify three recurrent discursive practices through which rationalistic and nationalistic discourses are enacted vis-à-vis the issues: factualizing, rationalizing and emotionalizing. These practices represent different ways of relating to the (re)construction of 'winners' and 'losers'. They can also be thought to exemplify the three classic elements of rhetoric: ethos, logos and pathos. Moreover, it should be noted that some discursive practices relate more readily to specific genres of printed journalism than others. For example, factualizing is likely to be found in (short) news reports, while columns and commentaries more readily provide a platform for rationalizing and emotionalizing.

\section{Factualizing}

The first discursive practice relates to the way 'facts' are established in the media. On the surface, the argumentative element in this practice appears to a large extent neutral with respect to the construction of 'winners' and 'losers' vis-à-vis particular issues. In other words, argumentation is not based on contradictions and/or controversies. In our press material, factualizing practices are particularly evident on the UK side. The following example is from the day after the merger between Astra and Zeneca was first announced:

'Drugs giant Zeneca yesterday unveiled the terms of its $£ 46$ billion merger with Swedish rival Astra and revealed that the deal will involve 6,000 job losses worldwide.' (Daily Telegraph, 10 December 1998)

This quote is in our view a good illustration of how issues are (re)constructed by factualizing. The journalist reproduces seemingly exact figures (probably supplied by the representatives of Zeneca) as 'facts'. The figures of speech 'unveiled' and 'revealed' are illustrative of how the source of the 'facts' is referred to. The abstract company (Zeneca) acts (announces figures). 
Other examples of factualizing include 'Zeneca and Astra share strengths in areas such as cardiovascular, respiratory and anaesthetics. Both have UK research facilities, suggesting scope for cost-cutting alongside sales synergies' (Financial Times, 17 August 1998) and 'The management will also begin a three-year programme to reduce the workforce by 6,000' (Daily Telegraph, 7 April 1999).

There is cause to ask whether factualizing as we have conceptualized it represents argumentation at all in a classic sense; the act of convincing is relatively implicit (cf. Perelman and Olbrechts- Tyteca, 1971; Perelman, 1977). Factualizing practices in the media have consequences, however, in the sense that they work to simplify the appearance of a complex phenomenon. Staff dismissals, for example, easily become taken-for-granted elements of mergers - and part of the horizon of expectations of media audiences (cf. Bourdieu, 1998b). In other words, the 'need' for 'rationalization' becomes naturalized in media texts on mergers (Vaara and Tienari, 2002).

Of the classic elements of rhetoric, factualizing perhaps best refers to ethos; a claim to credibility based on the authority of the speaker. Here, the 'Drugs giant' and 'The management' speak with authority through the media. It is also important to note the attribute 'Swedish rival' in the first textual example above. Even in a seemingly neutral, factualizing piece of text, the media constructs and reconstructs controversies (although it is not the basis for the argumentation). Locating these controversies requires, however, interpretation based on a 'close reading' of individual texts, and connecting it to other texts (cf. Fairclough, 1997).

\section{Rationalizing}

The second discursive practice identified relates in our view more directly and explicitly to acts of convincing and legitimization in the media. Rationalizing argumentation justifies specific states of affairs (issues; 'winners' and 'losers') by placing them within a framework of economic and financial rationale. Typically, then, rationalistic discourse is enacted by rationalizing. In the three classic elements of rhetoric it corresponds to logos; the logical or cogent argument. Specific states of affairs become further legitimized and naturalized as they are filled with particular meanings (cf. Vaara and Tienari, 2002).

The media searches for a rationale for why things are proceeding the way they appear to proceed. Our first example is on the division of ownership in AstraZeneca, where Zeneca is (re)constructed as the 'winner' in the deal: 
'Zeneca has learnt at least two lessons about drugs industry deals over the past few years. One is from Glaxo Wellcome's strength: get it done three years before the big patent expiry. The second is from Astra's weakness: get it done while your share price is strong. So Zeneca ends up as the larger partner despite Astra's drugs business being about two-thirds bigger.' (Financial Times, 12 December 1998)

So Zeneca ends up as the larger partner', period. Reversely, the construction of the 'loser' is also noteworthy here. When treating the division of ownership issue, for example, the Swedish media displays rationalizing argumentation which eventually legitimates the choice that gives Zeneca (UK) an advantage, a choice which at first glance seems unfair for shareholders of Astra:

'As opposed to the discount on Astra's stock price, Zeneca's stock was traded at a premium, as many expected a bid for the company. The risk of Zeneca being swallowed up by a larger competitor was a reason for Astra's management and board to close the deal in spite of the unfavorable ratio between the stocks' valuation.' (Veckans Affärer, 1 February 1999)

First, following up on the discussion on how the terms of the merger were calculated, it is 'admitted' in the text above that the price of Astra's shares was at a low point. The timing of the merger was in this sense unfortunate for the owners of Astra. Second, however, the risk of Zeneca being bought by another large company is presented as a rationale (for the owners of Astra) for closing the deal in spite of the seemingly unfavourable valuation. Hence, sentiments of 'losing' are rendered illegitimate by referring to economic rationality and the dynamic of the market. Simultaneously, the idea that a merger had to be carried out now becomes legitimized without opposition; at the end of the day, there was no real, rational alternative for Astra’s shareholders.

In similar vein, the issue of locating the headquarters of AstraZeneca in London serves as an example of rationalizing as discursive practice. As pointed out above, the question of moving the headquarters of major Swedish companies away from Sweden is a sensitive issue in Swedish society in general. It may be speculated that the issue of company headquarters moving out of Sweden hits the foundation of the Swedish 'people's home', based on a strong public sector (and tax revenues), in a hard way (cf. Berglund and Löwstedt, 1996). The 
merger between Pharmacia and Upjohn presents an illustrative example. The new company established a PO Box sales subsidiary in Luxembourg to minimize paying taxes in Sweden.

Locating the headquarters of AstraZeneca in London is thereby constructed as something that 'many perceive' as a 'national disaster for Sweden', with politicians playing the second violin to top managers in business (Affärsvärlden, 13 January 1999). However, this construction is neutralized in the media through references to the dynamics of the merger process, where 'there has to be an even distribution of the important functions'. The perceived 'national disaster for Sweden' is rationalized away by specific claims:

'The discussions about the headquarters may also have reduced the rise in stock value. That headquarters will be located in London and AstraZeneca will be seen as a British company has evoked strong emotions. Many perceive it as a national disaster for Sweden and wonder why politicians don't seem to care. But in a merger of two equally sized companies there has to be an equal distribution of the important functions. In this case, the headquarters and the CEO-title go to Zeneca, the responsibility for research goes to Astra in Södertälje and a Swede takes the role of chairman. A different mix, for example with research directed from London, would also have evoked negative reactions.' (Affärsvärlden, 13 January 1999)

The text above can also be interpreted to indicate that Astra and 'Sweden' are, in fact, not 'losers'. They have merely become part of a natural - and thereby just - division of power and authority in a cross-border merger; the name of the game is that you win some and you lose some. The issue at hand is rendered natural in the framework of economic and financial rationality that is now universal. What is at stake here is the good of the 'company' as an abstract notion. Argumentation is limited to the realm of an economic sphere. Nationalist sentiments are downplayed.

Finally, it seems that by rationalizing, journalists (re)construct templates that legitimize similar argumentation in other contexts. It must also be pointed out that it should also be possible to mobilize nationalistic discourse through rationalizing. This seems, however, to be considerably less frequent in the press material analysed.

\section{Emotionalizing}


The third discursive practice identified is instrumental in the (re)construction of the 'winner''loser' setting vis-à-vis particular issues in the AstraZeneca merger. It is instrumental in defining who 'wins' and who 'loses', and in rendering the setting potentially questionable.

Rather than downplaying conceptions of 'winning' and 'losing', emotionalizing argumentation produces and reinforces these conceptions. Different merger parties' specific interests are a point of departure here, rather than merely an obstacle in achieving 'rational' objectives (as is evident in factualizing and rationalizing). In the three classic elements of rhetoric emotionalizing corresponds to pathos; appealing to the audience's emotions. Typically, for example, nationalistic discourse is enacted by emotionalizing.

The following text is part of a relatively long article with the title 'Purchase Power: The Largest Companies are Involved in a Frenzy of Mergers and Acquisitions but the Benefits of This Third Industrial Revolution are Uncertain' (The Guardian, 20 July 1999). The last sentence in the text was previously presented as illustrative of nationalistic discourse in constructing an 'issue' (and a 'winner'-'loser' setting) in the media. Below, we discuss the discursive practice involved in more detail:

'Britain's Zeneca merged with Sweden's Astra in an effort to share the R\&D effort at
a time when ever more needs to be put into it. The creation of Euroland around the
single currency has encouraged both national and cross-border financial services
deals. Is agglomeration beneficial? Promises made at the time of takeover, in terms
of synergies and cost savings, are rarely fulfilled. When, after a merger, the owners
are foreign, the final arbiters on investment and jobs are even further removed from
the cutting edge. That can work two ways. BMW's decision to concentrate
production in Britain is almost certainly beneficial; it will build quality into British-
produced cars. But Zeneca has moved its R\&D headquarters to Stockholm, which
may weaken the R\&D base in pharmaceuticals - one of the few areas where Britain
possesses a genuinely world-class industry.' (Guardian, 20 July 1999)

This extract is worthy of particular attention. First, 'Britain's Zeneca' is contrasted in the first sentence to 'Sweden's Astra', thus setting a clear agenda for national juxtaposition; 'us' versus ‘them' (cf. Billig, 1995). 'Promises’ made by AstraZeneca - among other companies now appear questionable. In this text, 'foreign owners' as 'final arbiters' clearly do not represent the 'cutting edge'. Against a contrary, positive example (BMW), AstraZeneca's 
decision to locate research and development operations outside the United Kingdom is deemed potentially harmful for the company in the future.

'Britain' is reconstructed as a nation, and nationalistic discourse spelling out British superiority is in evidence here (cf. Risberg et al., 2000). This is done by emotionalizing the issue at hand. First, the concept of 'foreign', used in a way that can be interpreted as negative, occupies a central role in the text. Second, the text draws from collective memory in the UK; a traumatic earlier event where the German automobile company BMW acquired the traditional Rover brand is portrayed to have become 'beneficial' as production was not moved away from Britain. Third, Swedish control is left to hover as a Damoclean sword over the new company. Note the reference to Stockholm; the city of Södertälje is non-existent, too small and unknown to be worthy of reference to the readers of the Guardian.

Swedish media texts illustrating nationalistic discourse were also presented earlier in this article. The text below aptly demonstrates the emotionalizing discursive practice:

'How does the future look for the employees of Astra in Södertälje, when the headquarters is in London and the center of research in Södertälje? Astra has invested 2-3 billion S.Kr. a year in development during the past 10 years. The inflow of people has been considerable and the outflow limited. The headquarters in Södertälje has about 5,600 employees, almost as many as the number of people by which the 60,000 work force should be reduced in the new concern. How stable will the Astra Zeneca marriage be, and whose kids will be locked out when the honeymoon is over? This question is in the air at the production line in Södertälje. The calm is deceptive. Everyone hopes it will work out all right. It is claimed that the problem of the 6,000 people who have to go will be solved in the next three years by not replacing those that leave, the union chair for Sif [whitecollar workers' association], Raymond Nygren, explains, and hopes that the prognosis will come true.' (Dagens Nyheter ekonomi, 18 December 1998)

In our view, the core of the text above is the sentence 'How stable will the AstraZeneca marriage be, and whose kids will be locked out when the honeymoon is over?'. This is an explicit play with emotional meanings in a business context. Because the journalist has chosen this mode of representation from a range of alternatives, the sentence can be interpreted to serve a particular function in the textual totality. The marriage metaphor is 
activated and the potential hardships in an unstable family are emphasized. The marriage is portrayed as a struggle including 'winners' and 'losers'. The metaphoric portrayal of employees as children (potentially) deceived by their parents is particularly interesting. There is also an element of localization involved; little Södertälje is contrasted to mighty London. 'The calm is deceptive' from a local (Swedish) perspective. It is also crucial to note that the 'problem of the 6,000 people who have to go' itself is not subject to criticism. Rather, the issue of staff dismissals is becoming legitimized and naturalized, as was pointed out earlier (cf. Vaara and Tienari, 2002).

In sum, the discursive practice of emotionalizing seems to abandon the 'universal' or 'abstract' level, and to some extent localizes the merger discussion by dealing with questions of its consequences for specific peoples and/or a specific territory. This seems to question the universal economic rationality underlying the rationalizing arguments and prepares the ground for wider discussions of the positive and negative consequences of the merger in question.

\title{
How discursive practices intertwine
}

Disentangling various discourses and discursive practices helps to address the specific meanings assigned or fixed to complex phenomena, such as the cross-border merger between Astra and Zeneca. Our distinction of discursive practices is, however, first and foremost an analytical effort and thus open to critical scrutiny. Discourses and discursive practices intertwine in individual media texts. The following text in the Swedish business outlet Finanstidningen, discussing the Stockholm Stock Exchange as a 'losing' actor in the AstraZeneca merger, is a good example of this. The text was published immediately after the initial merger announcement:

\begin{abstract}
'The Stockholm Stock Exchange may become one of the losers in Astra's merger with Zeneca. The new company will also be listed in New York and London, where most of the trading is expected to take place. The large proportion of foreign ownership creates fears that the Stockholm Stock Exchange may lose trading in
\end{abstract} Astra-Zeneca stock to London and New York.' (Finanstidningen, 10 December 1998)

Claims about Swedish society losing out on the headquarters issue are, again, in evidence here. As the AstraZeneca merger is placed in a wider context of national 'loss', the Stockholm Stock Exchange can (also) be interpreted to represent the 'Swedish nation' here. In addition, 
this text aptly illustrates how the voice of the so-called expert (here, the analyst) is shaping journalism:

'If the deal is closed, and the stock is listed in Stockholm, London and New York, more of the trading will take place in London, Mikael Malmquist, manager of trading at Aros Securities, says to Finanstidningen. Fti [Finanstidningen]: Will the Stockholm Stock Exchange lose on this? - Yes, as there are more and larger Londonbased institutional owners than Stockholm-based, this will probably be the case, says Malmquist. The Astra Zeneca deal is the latest in a series of large mergers involving Swedish companies. According to Mikael Malmquist, this trend increases the risk of the Stockholm Stock Exchange losing trade to other market places.' (Finanstidningen, 10 December 1998)

It is important to note that the voice of the 'expert' merely speculates about the future. As the article goes on, depicting the Stockholm Stock Exchange as the 'loser' is quickly neutralized by making the 'loss' appear a natural development driven by the economic forces of the market, i.e. competition:

\footnotetext{
'It is sad when all the large beautiful companies are flagged out or half-flagged out in one way or another. It is a pity for Stockholm as a financial market place. This is, of course, subject to competition, and when the large Swedish companies merge, or are acquired by foreign companies, it is a natural consequence that some of the trading in their stock takes place in their new local markets, Malmquist continues. Other stockbrokers claim it is too early to say anything substantial about where AstraZeneca stock will be traded. What is decisive is where the owners are and which stock exchange offers the best terms for doing business.' (Finanstidning, 10 December 1998)
}

In our view, the ways in which nationalist sentiments bring a particular emotional flavour to the text, but are rationalized away as illegimite, are especially interesting in this text. 'It is sad when all the large beautiful companies' and 'It is a pity', but 'This is, of course, subject to competition', and 'it is a natural consequence'. Finally, the forces of the global market will decide the fate of the company: 'which stock exchange offers the best terms for doing business'. This text is a typical example in the press material studied, especially in the 
business outlets. In sum, rationalistic and nationalistic discourses, and the discursive practices in which they are enacted, both compete with and support each other.

\section{Conclusion}

It is evident that the conventions and practices of mass media carry wider significance in the ways in which specific representations of the world are imposed on the general public (cf. Fairclough, 1995). In this article, we have attempted to make explicit some of the practices in the business and popular press in assigning particular meanings to 'reality'. We have examined how the media socially (re)constructs a cross-border merger between two companies. We have put forward a novel framework for exploring difference and contradiction in the merger context, and specified and illustrated how particular issues become (re)constructed in media texts through interpretations of 'winning' and 'losing'. Furthermore, we have demonstrated the discourses journalists draw on in this (re)construction, and specified through which types of practices the discourses are enacted.

Our analysis of media texts on the merger between Astra (Sweden) and Zeneca (UK) indicates that the construction of a 'winner'-'loser' setting centred around four main issues: (1) division of ownership, (2) distribution of top management positions, (3) locations, and (4) staff reductions. When these issues are (re)constructed in media texts, specific discourses are drawn on. The present study confirms the argument that discourse based on economic and financial rationale dominates public discussion on mergers and acquisitions (cf. Vaara and Tienari, 2002). It points also to the suggestion that nationalistic discourse provides an alternative discursive framework in (re)constructing issues in the context of a cross-border merger (see also Risberg et al., 2000). Specifically, the present analysis indicates that media texts on the 'winning' side tend to construct each issue in question in an apparently rational, neutral and matter-of-fact way, while the 'losing' side also tend to revert to nationalistic considerations.

We identified three analytically distinct practices through which rationalistic and nationalistic discourses become enacted in specific instances with particular consequences (cf. Fairclough, 1997). We label these practices factualizing, rationalizing and emotionalizing. The practices are grounded in the efforts of the media to objectify complex and ambiguous phenomena such as a merger between two companies. Factualizing practices refer to the ways in which brief news-type reporting establishes particular statements as 'facts'. Rationalizing builds on 
various types of 'logical' arguments as universal explanations for particular states of affairs, which then become legitimized and naturalized in the media coverage. Emotionalizing localizes the discussion by dealing with questions relevant for specific peoples and/or a specific territory, questioning universal rationalities and opening up for wider discussions the phenomena at hand. Through discursive practices such as factualizing, rationalizing and emotionalizing, journalists convince their readers of specific claims; here, in constructing 'winners' and 'losers' in relation to specific issues. The (re)construction of the 'loser' is particularly interesting. In rationalizing, for example, the significance of 'losing' (or winning) from a 'national' perspective is rendered irrelevant and even illegitimate. In emotionalizing, a more complex picture is painted.

Our study indicates that the willingness - and/ or possibilities - of the press to engage in critical discussions of mergers and acquisitions is limited. The rationalizing practice perhaps could have provided a means for questioning the concept of 'merger' more generally, but in the present context this practice was typically used to neutralize the negative effects of the specific merger at hand. Rendering the interests of a specific 'nation' illegitimate seems to be based on taken-forgranted assumptions in today's apparently global business which depicts the world as increasingly interconnected and 'similar' (cf. Strang and Meyer, 1993). In our view, this practice reflects the importance of language and semiosis in the continuous (re)construction of the neo-liberal global order (Bourdieu, 1998a, 1998b; Fairclough, 2000).

In sum, it seems that the press contributes to a narrowing-down of the discussion on the 'merger' to the perspectives represented by management rather than encouraging and directing a broad and reflective discussion on the phenomenon itself. In reference to the above, it does not seem sufficient to explain this narrowing down through individual outlets' and journalists' increasing pressures for time and media space. Rather, it seems that there is a political or ideological element involved. Discursive practices reveal the choices journalists have in constructing their texts; which voices come to dominate the discussions and which are marginalized or excluded.

We suggest that the way powerful actors such as top managers and owners' representatives are able to orchestrate public discussion by getting their versions of 'reality' factualized and rationalized and eventually naturalized in favourable ways in the media presents an important challenge for critical management and organization scholars. Processes of sense-giving and sense-making are not constrained by organizational boundaries. How managers 'manage 
through the media' needs to be studied in detail. An approach focusing on specific actors' discursive strategies (cf. Hardy et al., 2000) is likely to contribute to the cultural literature on mergers and acquisitions.

Finally, and more generally, we acknowledge that the question of the extent to which different discursive practices play to different audiences has not been discussed in sufficient detail in the present article (cf. Bourdieu, 1998a). This presents another crucial avenue for future research on media texts. Anecdotes from the material studied suggest that genres of newsmaking are becoming blurred (cf. Fairclough, 1995); news texts are becoming flavoured by more subjective commentary. The present material also suggests that the managerialistic, rationalistic discourse is extending its influence from outlets targeted at business professionals to outlets with wider, popular audiences. The underlying ideological assumptions and consequences of this trend call for attention. The popularization of management 'knowledge' in mass media (cf. Mazza and Alvarez, 2000) should not be treated as a natural and unproblematic development.

\section{References}

Anderson, B. (1983). Imagined Communities: Reflections on the Origin and Spread of Nationalism. Verso Editions and NLB, London.

Berglund, J. and J. Löwstedt (1996). 'Sweden: the Fate of Human Resource Management in a “Folkish” Society’. In: T. Clark (ed.), European Human Resource Management, pp. 215-243. Blackwell, Oxford.

Billig, M. (1995). Banal Nationalism. Sage Publications, London. Blomström, M. (1990). 'Competitiveness of Firms and Countries'. In: J. H. Dunning, B. Kogut and M. Blomström (eds), Globalization of Firms and the Competitiveness of Nations. Lund University/Institute of Economic Research, Lund, Sweden.

Bourdieu, P. (1998a). On Television. The New Press, New York. Bourdieu, P. (1998b). Acts of Resistance - Against the New Myths of Our Time. Polity, Cambridge.

Buono, A. F., J. L. Bowditch and J. W. Lewis III (1985). 'When Cultures Collide: The Anatomy of a Merger', Human Relations, 38(5), pp. 477-500. Calori, R., M. Lubatkin and P. 
Very (1994). 'Control Mechanisms in Cross-Border Acquisitions: An International Comparison', Organization Studies, 15(3), pp. 361-379.

Cartwright, S. and C. L. Cooper (1990). 'The Impact of Mergers and Acquisitions On People At Work: Existing Research and Issues’, British Journal of Management, 1(1), pp. 65-76.

Chatterjee, S., M. H. Lubatkin, D. M. Schweiger and Y. Weber (1992). 'Cultural Differences and Shareholder Value in Related Mergers: Linking Equity and Human Capital', Strategic Management Journal, 13(5), pp. 319-334.

Chomsky, N. (1999). Profit Over People - Neoliberalism and Global Order. Seven Stories, New York. Datta, D. K. (1991). 'Organizational Fit and Acquisition Performance: Effects of Post-Acquisition Integration', Strategic Management Journal, 12(4), pp. 281-297.

Davis, G. F. and S. K. Stout (1992). 'Organization Theory and the Market for Corporate Control: A Dynamic Analysis of the Characteristics of Large Takeover Targets, 1980-1990', Administrative Science Quarterly, 37(4), pp. 605-633

De Cillia, R., M. Reisigl and R. Wodak (1999). 'The Discursive Construction of National Identities', Discourse and Society, 10(2), pp. 149-173.

Duhaime, I. M. and C. R. Schwenk (1985). 'Conjectures on Cognitive Simplification in Acquisition and Divestment Decision Making', Academy of Management Review, 10(2), pp. 287-295.

Dutton, J. E. and J. M. Dukerich (1991). 'Keeping an Eye on the Mirror: Image and Identity in Organizational Adaptation', Academy of Management Journal, 34(3), pp. 517-554.

Ericson, M. (1991). Iggesundsaffären: Rationaliteter i en strategisk förvärvsprocess. [The Iggesund Affair: Rationalities in a Strategic Acquisition Process]. EFI, Stockholm.

Fairclough, N. (1995). Media Discourse. Edward Arnold, London.

Fairclough, N. (1997). Critical Discourse Analysis: The Critical Study of Language (2nd edn). Addison Wesley Longman, London.

Fairclough, N. (2000). 'Guest Editorial: Language and Neoliberalism', Discourse and Society, 11(2), pp. 147-148. 
Fournier, V. (1998). 'Stories of Development and Exploitation: Militant Voices in an Enterprise Culture', Organization 5(1), pp. 55-80.

Frommer, R. (2001). Between Expectation and Experience - An Analysis of Post-Merger Integration in Two Mergers. Doctoral Dissertation, The Royal Institute of Technology, Stockholm, Sweden.

Gertsen, M. C., A.-M. Söderberg and J. E. Torp (1998), 'Different Approaches to the Understanding of Culture in Mergers and Acquisitions'. In: M. C. Gertsen, A.-M. Söderberg and J. E. Torp (eds), Cultural Dimensions of International Mergers and Acquisitions, pp. 1738. De Gruyter, Berlin.

Gioia, D. and K. Chittipeddi (1991). 'Sensemaking and Sensegiving in a Strategic Initiation’, Strategic Management Journal, 12(6), pp. 433-448.

Hardy, C., I. Palmer and N. Phillips (2000). 'Discourse as a strategic resource', Human Relations, 53(9), pp. 1227-1248.

Haspeslagh, P. and D. B. Jemison (1991). Managing Acquisitions: Creating Value through Corporate Renewal. Free Press, New York.

Hellgren, B. and J. Löwstedt (2001). 'An Introduction to Management in the Thought-full Enterprise'. In: B. Hellgren and J. Löwstedt (eds), Management in the Thought-full Enterprise, pp. 7-33. Fagbokforlaget, Bergen.

Hellgren, B., J. Löwstedt and A. Werr (2000). 'The Reproduction of Efficiency Theory: The Construction of the AstraZeneca Merger in the Public Discourse', paper presented to the 4th International Conference on Organizational Discourse, Kings College, London, UK, July 2628.

Hirsch, P. M. (1986). 'From Ambushes to Golden Parachutes: Corporate Takeovers as an Instance of Cultural Framing and Institutional Integration', American Journal of Sociology 91(4), pp. 800-837. Kitching, J. (1967). ‘Why Do Mergers Miscarry?’, Harvard Business Review, 45, 84-101. 
Krug, J. A. and W. H. Hegarty (1997). ‘Post-acquisition Turnover Among U.S. Top

Management Teams: An Analysis of the Effects of Foreign vs. Domestic Acquisitions of U.S. Targets’, Strategic Management Journal, 18, pp. 667-675.

Kuronen, M.-L., J. Tienari and E. Vaara (2001). 'The Merger Storm Recognises No Borders An Analysis of Media Rhetoric On a Business Manouver', paper presented to the 17th European Group for Organization Studies (EGOS) Colloquium 'The Odyssey of Organizing', Lyons, France, 5-7 July.

Larsson, R. and M. Lubatkin (2001). 'Achieving Acculturation in Mergers and Acquisitions: An International Case Survey’, Human Relations, 54(12), pp. 1573-1608.

Llewellyn, S. (2000). 'A to Z Integration?: Managing the Merger at AstraZeneca', paper presented to the 16th EGOS Colloquium, Helsinki School of Economics and Business Administration, Finland, July 2-4.

Low, M. (2000). 'Nationalism’. In: G. Browning, A. Halcli and F. Webster (eds), Understanding Contemporary Society: Theories of the Present, pp. 356-371. Sage Publications, London.

Lubatkin, M. H. and P. J. Lane (1996). 'Psst ... The merger mavens still have it wrong!', Academy of Management Executive, 10(1), pp. 21-39.

Lubatkin, M., R. Calori, P. Very and J. Veiga (1998). 'Managing Mergers Across Borders: A Two Nation Test of Nationally Bound Administrative Heritage', Organization Science, 9(6), pp. 670-684.

Mazza, C. and J. L. Alvarez (2000). 'Haute Couture and Pret-a-Porter: The Popular Press and the Diffusion of Management Practices’, Organization Studies, 21(3), pp. 567-588.

Meyer, C. B. (2001). 'Allocation Processes in Mergers and Acquisitions: An Organizational Justice Perspective’, British Journal of Management, 12(1), pp. 47-66.

Morosini, P., S. Shane and H. Singh (1998). 'National Cultural Difference and Cross-Border Acquisition Performance', Journal of International Business Studies, 29(1), pp. 137-158.

Nahavandi, A. and A. R. Malekzadeh (1988). 'Acculturation in Mergers and Acquisitions', Academy of Management Review, 13(1), pp. 79-90. 
Napier, N. K. (1989). 'Mergers and Acquisitions, Human Resource Issues and Outcomes: A Review and Suggested Typology’, Journal of Management Studies, 26(3), pp. 271-289.

Napier, N. K., G. Simmons and K. Stratton (1989). 'Communication During a Merger: Experience of Two Banks', Human Resource Planning, 12, pp. 105-122.

Olie, R. (1994). 'Shades of Culture and Institutions in International Mergers', Organization Studies, 15(3), pp. 381-405.

Pablo, A. L. (1994). 'Determinants of Acquisition Integration Level: A Decision-making Perspective', Academy of Management Journal, 37(4), pp. 803-836.

Perelman, C. (1977). L'empire rhétorique. Rhétorique et argumentation. [The Empire of Rhetoric. Rhetoric and Argumentation]. Librairie Philosophique J.VRIN.

Perelman, C. and L. Olbrechts-Tyteca (1971). The New Rhetoric: A Treatise on Argumentation. University of Notre Dame Press, Notre Dame (Original: La Nouvelle Rhétorique: Traité de l’Argumentation. Presses Universitaires de France 1958).

Risberg, A. (1999). Ambiguities Thereafter: An Interpretive Approach to Acquisitions. Lund University Press, Malmö.

Risberg, A., J. Tienari and E. Vaara (2000). 'Legacies of Superiority and Inferiority: Media Texts and Sense Making of a Merger Across National Boundaries', paper presented to the 18th Standing Conference on Organizational Symbolism (SCOS), Athens, Greece, 5-9 July.

Schneider, S. C. and R. L. M. Dunbar (1992). 'A Psychoanalytic Reading of Hostile Takeover Events', Academy of Management Review, 17(3), pp. 337-567.

Schweiger, D. M. and A. S. DeNisi (1991). 'Communication with Employees Following a Merger: A Longitudinal Field Experiment', Academy of Management Journal, 34(1), pp. $100-135$.

Schweiger, D. M., J. M. Ivancevich and F. R. Power (1987). 'Executive Action for Managing Human Resources Before and After the Acquisition', Academy of Management Executive, 1(2), pp. 127-138. 
Strang, D. and J. W. Meyer (1993). 'Institutional Conditions for Diffusion’, Theory and Society, 22, pp. 487-512.

Thornton, P. (1995). 'Accounting for Acquisition Waves: Evidence from the U.S. College Publishing Industry’. In: W. R. Scott and S. Christensen (eds), The Institutional Construction of Organizations: International and Longitudinal Studies, pp. 199-225. Sage, Thousand Oaks, CA.

Tienari, J. (2000). 'Gender Segregation in the Making of a Merger', Scandinavian Journal of Management, 16(2), pp. 111-144.

Trautwein, F. (1990). 'Merger Motives and Merger Prescriptions', Strategic Management Journal, 11, pp. 283-295.

Vaara, E. (2000). 'Constructions of Cultural Differences in Post-merger Change Processes: A Sensemaking Perspective on Finnish-Swedish Cases’, M@n@gement, 3, pp. 81-110.

Vaara, E. (forthcoming), 'On the Discursive Construction of Success/Failure in Narratives of Post-merger Integration’, Organization Studies.

Vaara, E. and J. Tienari (2002). 'Justification, Legitimization and Naturalization of Mergers and Acquisitions: A Critical Discourse Analysis of Media Texts', Organization, 9(2), pp. 275-303.

Very, P., M. H. Lubatkin and R. Calori (1998). 'A Cross- National Assessment of Acculturative Stress in Recent European Mergers’. In: M. C. Gertsen, A.-M. Söderberg and J. E. Torp (eds), Cultural Dimensions of International Mergers and Acquisitions. De Gruyter, Berlin.

Weick, K. (1995). Sensemaking in Organizations. Sage Publications, Thousand Oaks, CA. 